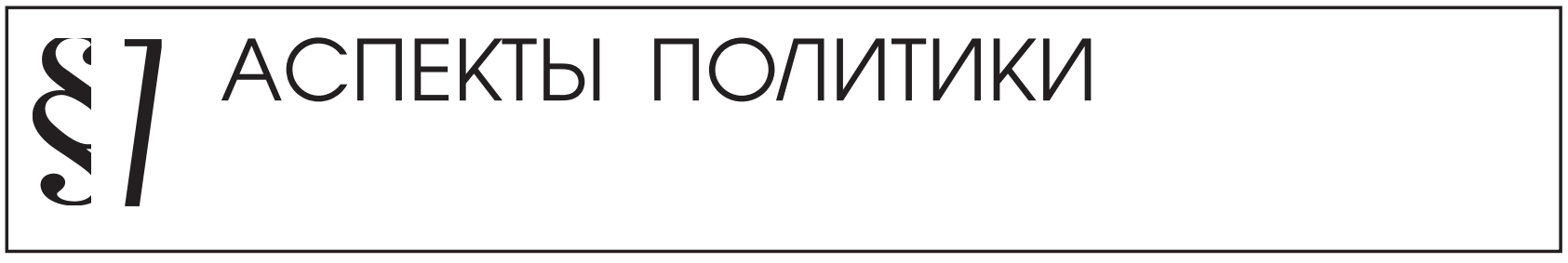

Ханнанова Т.P.

\title{
ОБЪЕКТИВНАЯ ПРИРОДА РАСТЕНИЕВОДСТВА КАК ФАКТОР ФОРМИРОВАНИЯ И РЕАЛИЗАЦИИ АГРАРНОЙ ПОЛИТИКИ ГОСУДАРСТВА
}

\begin{abstract}
Аннотация: Аграрная политика российского государства в сфере растениеводства, к сожалению, недостаточно эффективна. Одним из важнейших факторов, отрицательно влияющих на формирование и реализачию государственной политики в этой подотрасли сельского хозяйства, является системное игнорирование политическими акторами объективного факта природной предопределенности всех элементов названной политики. В статье доказывается, что объективная природа растениеводства является фактором формирования и реализачии аграрной политики государства, качество которой, в свою очередь, обуславливает эффективность и устойчивость сельскохозяйственного производства. Имеющиеся в настоящее время политические решения и нормативные акты, посвященные развитию сельского хозяйства, носят несистемный разрозненный характер, принимаются по случаю каких-либо неблагоприятных событий в аграрном секторе и также не учитывают природной спечифики растениеводства, не имеют опоры и на природу самого человека - естественного носителя сельского образа жизни и труда, что влечет за собой нигилизм и недоверие сельхозтоваропроизводителей к аграрной политике государства.

Review: Agricultural policy of the Russian Federation is not so effective in the sphere of plant growing unfortunately. One of the most important factors that have a negative impact on formation and implementation of state policy in this branch of agricultural economy is the systematic ignorance of the nature influencing each element of the aforesaid policy. The author of the article proves that nature should be taken into account when forming and implementing agricultural policy. In its turn, good agricultural policy contributes to efficient and sustainable agricultural production. Current political solutions and regulatory acts devoted to agricultural development are not systematic. They are taken into account only when there is an unfavorable situation in the agricultural sector. These acts and solutions rarely consider the influence of natural forces on the process of plant growing and even more rarely they consider the influence of human himself as a natural agricultural worker. This leads to nihilism and mistrust of agricultural producers towards state agricultural policy.
\end{abstract}

Ключевые слова: растениеводство, природа, аграрный, государство, политика, актор, эффективность, объективный, приоритет, иель

Keywords: plant growing, nature, agricultural, state, politics, actor, efficiency, objective, priority, purpose.

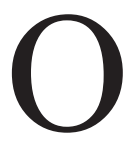

течественная наука доказывает и показывает, что растительный мир был результатом эволюционного развития природы в силу закономерно повторяющихся в ее недрах внутренних причинно-следственных связей, неуправляемой людьми биогенной миграции атомов, обуславливающей сохранение своей целостности в саморегулируемом состоянии ${ }^{1}$. Благодаря этому

1 Подробно о причинах и предпосылках зарождения он стал первоначальным, объективно возникшим органическим составляющим мироздания, предопределяющим не только естественный компонент реальной действительности, но и содержание об-

и бытия природных компонентов мира см. События в системе правового обеспечения модернизации социально-экономического развития России: теория и практика / Р.А. Ханнанов, Т.Р. Ханнанова. - Уфа: Башкирский ГАУ, АН РБ, 2012. - 162 с. С. 16-26, 36-44. 
щественного бытия (общества) как целостного, интегрированного материальными условиями жизни социального организма, функционирующего на основе саморегуляции и развивающегося через разрешение внутренних противоречий ${ }^{2}$.

Растительное сообщество (фитоценоз), будучи в своей основе природным явлением, онтогенетически сформированным и формирующимся обстоятельством, тем не менее, в рамках человеческого общества приобретает значимость всеобщего, так или иначе относящегося к общественному сознанию, присутствующего во всех его проявлениях в виде бинарной оппозиции природного и общественного, генуинного и социального. Тем самым оно становится одновременно неотъемлемым элементом как материального производства (объективного), так и решающим фактором упорядочения связей по государственному, экономическому и индивидуальному регулированию (субъективного).

Такая сущность рассматриваемого сообщества в плане его социально-экономических индикативных возможностей не представляется необоснованной. Она подтверждается всем ходом исторического развития природы и общества, происходящего в рамках всеобщего универсального объективного закона саморегуляции природы ${ }^{3}$, а также организацией и ведением растениеводства в рамках рационального сочетания объективного с субъективным, учета их совместных конъюгационных взаимозависимостей. По мнению отдельных ученых, в питании человека растительные продукты занимают около 90\% общей потребности в энергии, потребность человека в белках, жирах, углеводах за счет растений удовлетворяется на $80-90 \%{ }^{4}$. В процессе фотосинтеза растения способны создавать указанные органические вещества из неорганических (диоксида углерода, воды, минеральных солей) с ис-

\footnotetext{
2 Краснов B.M. К понятию общества как социальной системы // Философские науки. 1977. № 2. С. 28.

${ }^{3}$ Ханнанов Р.А., Ханнанова Т.Р. Указ. Соч. С. 65-114; их же. Модернизация государственной аграрной политики государства. - Уфа, Академия наук РБ, ФГБОУ ВПО «Башкирский государственный аграрный университет», 2013. 484 с. - С. 4-237.

${ }^{4}$ Алабушев В.А., Алабушев А.В. Растениеводство / Под ред. Алабушева В.А. - Ростов н/Д, Издательский центр «Март», 2001. 384 с. - C. 3.
}

пользованием энергии солнца. Растения предоставляют людям не только продукты питания, но и сырье для промышленности, животным - корма, биосфере - кислород 5 Здесь природное всецело предопределяет субъективное, в свою очередь, в последнем предвосхищается объективное.

Следует, однако, отметить то, что дуалистическая сущность растениеводства не находит своего заинтересованного, целесообразного осознания, познания и признания в агрохозяйственной практике, не используется в ней. Проблема в обозначенном контексте существует и охватывает как биологическую и физико-климатическую сторону (накопление солнечной энергии в процессе фотосинтеза; традиционно устоявшееся и ставшее непререкаемым редукционно-рецессивное земледелие; благоприятные почвенно-климатические условия производства продукции и другие, не поддающиеся или неполно поддающиеся контролю явления событийного характера), и волевую, дискреционную сторону (альтернативное, интенсивное и адаптивное возделывание культур). Указанные стороны требуют сочетаемого взаимосвязанного применения. В отдельности желаемого результата они не приносят. Повышение урожайности культур и рост сборов не достигаются или же достижения оказываются незначительными, что, в частности, подтверждалось имевшими место фактами волевого насаждения производства культур (например, «заморского» картофеля), травопольной и паропропашной систем земледелия, необоснованной повсеместной мелиорации и т.д.

Негативное отношение политических акторов к отмеченной сущности растениеводства ведет к постепенному формированию и наступлению вредных пернициозных (гибельных, опасных) последствий в сфере хозяйствования, начинающих приобретать все более перманентный характер. Культивируемые сельскими производителями растения получают мизерные объемы органических удобрений или вовсе их не получают из-за их отсутствия, вызванного сокращением поголовья скота, свертыванием подотрасли животноводства. Как следствие этого, теряется плодородие почв, заодно с ним снижаются проектируемые

\footnotetext{
${ }^{5}$ Коренев Г.В., Федотов В.А., Попов А.Ф. и др. Растениеводство. - М.: Колос, 1999. - 368 с. - С. 3.
} 


\section{Политика и общество 10 (106) • 2013}

урожаи и сборы продукции. Самое печальное при таком варианте осуществления растениеводства - инициируется пагубная для всего сельского хозяйства биологическая усталость земельных угодий, приводящая к выводу пашни из оборота, колоссальным потерям продукции и убыткам. Более того, на «уставших» от некомпетентного, варварского подхода к земле почвах создаются условия для развития и распространения вредных насекомых и болезнетворных грибков, а также сорных растений. Сельскохозяйственные производители вынуждены бороться с подобными «сожителями» культурной растительности, неся огромные имущественные расходы, связанные с их уничтожением и оздоровлением угодий от привнесенных инсектофунгицидами и фитофагами ядовитых веществ (моли, тли, клопы, блошки, клещи, мухи, долгоносики, галлицы и др. насекомые; фузариоз, мучнистая роса, ржавчина, заразиха, бель, фомоз, корнеед, церкоспороз, фитофтора, рак, парша, черная ножка, кила, некроз и ряд вирусных и грибковых болезней).

Особую опасность для растений представляют саранчовые насекомые (саранча, луговой кузнечик и др.), обладающие неимоверными способностями к биологическому размножению популяций и прожорливостью, большой подвижностью и широкой пространственной размещаемостью. При захвате посевов культурной растительности они оставляют за собой опустошенные поля и луга, съедая все органические части растений, листья, соцветия, стебли и плоды, заражая, в то же время, все «оккупированные» ими площади яйцами, тем самым инстиктивно создавая условия для дальнейшего развития своих поколений в будущем.

Природа жизнеобеспечения саранчовых достаточно изучена. Несмотря на саморегулирующий характер сожития саранчевых, присущую им естественную, обусловленную законом саморегуляции природы, приспособляемость к окружающим условиям возрождения и процессного развития, наука и практика не обращают на эти очевидные природные факты должного внимания. Необходимость учета при разработке мер по борьбе с саранчовыми признается лишь в плане уничтожения их с помощью ядохимикатов (инактофунгицидов) и только на поздних этапах пребывания особей на стадиях имаго. На данной стадии яйца саранчовых сохраняются и становятся реальным подспорьем для продолжения ими жизни в предопределенном биологией режиме и объективной данности, а почвы, используемые в растениеводстве, получают значительную долю зараженности ядами, усваиваемыми сельскохозяйственными культурами, провоцируя соматические заболевания у людей и животных.

На наш взгляд, борьбу с саранчовыми нужно вести на всех этапах их бытия, начав эту деятельность со стадии яйцекладки, охватывая все стадии становления (личинки, окукливания и имаго). Такой деятельности должна предшествовать целенаправленная научная проработка проблемы, данные которой, после юридического и политического осознания и признания, следует заложить в основу общегосударственной проблемы борьбы с саранчовыми, причем, проблемы политического масштаба. В качестве мер борьбы с названными насекомыми можно предложить выявление таких их природных врагов, как богомола, создать для них условия для разведения, использовав в этом направлении зональные инсектарии с соответствующей материальной базой, лабораториями.

Претворение этих рекомендаций в систему агропрома явилось бы «образцом для подражания» и стало бы оправданным, экономически выгодным, более предпочтительным, чем применение ядохимикатов, мероприятием в борьбе и с другими вредными насекомыми, например, такими их разновидностями, как колорадский жук и свекловичные блошки и им подобными врагами растениеводства.

В настоящее время неизмеримо более значительную опасность представляет засоренность посевов культурных растений. Вся территория пашни России заражена семенами сорной растительности. Сорняки в стране стали и прочно утвердились в качестве растительного сообщества, занимая в сельском хозяйстве место специфического фитоценоза - катастрофического состояния земледелия и растениеводства. Борьба с засоренностью полей становится, как это отмечалось выше, неотъемлемым аргументом аграрного (сельскохозяйственного) производства, решающим фактором повышения его эффективности и устойчивости, требующим сознательного регулирования со стороны всех участников агро- 
хозяйственного процесса. В этом деле велико значение политико-правовых усилий, предпринимаемых в рамках аграрной политики России 6 .

В пернициозном состоянии находятся все обрабатываемые угодия страны. В них почти повсеместно образована плужная подошва как закономерно возникшее следствие использования массивной сельскохозяйственной техники. Подошва уплотняет почву, постепенно разрушая ее структуру, тем самым выводя пашню из хозяйственного оборота. Ущерб от нее огромен, но никем не измерен, что, разумеется, мешает разработке соответствующих ее содержанию и природе физико-механических и биолого-химических мероприятий. В ряде хозяйств России, в частности в Республике Башкортостан, для уничтожения плужной подошвы прибегают к помощи долотообразных лап, вмонтируемых в культиваторы, либо же вводят в севообороты культуры со стержневыми системами корней, глубоко проникающие вглубь почвы (до 1-3 м) и позволяющие доставать влагу из низколежащих пластов грунта.

К сожалению, применение подобных физико-биологических приемов обработки почв, использование возможностей, заложенных в самой природе, является, пожалуй, исключением из общих правил воздействия на почвенные процессы, нежели системой. Адаптивноконтурные системы земледелия, действующие в регионах, почему-то не включают рекомендации, посвященные борьбе с плужной подошвой ${ }^{7}$. По большому счету изучение, разработка мер борьбы и разрешение проблемы не могут ограничиваться региональными уровнями, а достойны внимания органов федеральной власти и хозяйственного управления, ибо эта проблема охватывает всю территорию растениеводства страны, сферу его научного, техникотехнологического, материально-технического, финансового и производственного обеспечения. Предложенный подход к проблеме способен инспирировать максимизацию валовой

\footnotetext{
${ }^{6}$ Ханнанова T.P. Государственная аграрная политика: проблемы объективации // Право и политика. 2013. 34. C. 498 .

7 Система ведения агропромышленного производства в Республике Башкортостан. - Уфа.: АН РБ, Гилем, 2012. -528 c.
}

продукции растениеводства, предвосхищать благополучие, жизнеобеспечение населения ${ }^{8}$.

Развитие растениеводства возможно лишь при осознании факта наличия природно обусловленных рисков и вызываемых ими последствий, нуждаемости его в прогнозируемом и адаптационном режимах. Без такого подхода к осуществлению подотрасли немыслимо превращение ее в наукоемкий и высокомодернизированный сектор аграрной отрасли. Это означает, что в сельском хозяйстве, в первую очередь, в его растениеводческой составляющей, нужно обеспечить воспроизводство и повышение эффективности использования естественных ресурсов, возможностей, заложенных в природе человекакрестьянина и в самом аграрном производстве. Несмотря на, казалось бы, очевидность отмеченного, объективная сторона проблемы органами власти и хозяйственного управления, а также самими непосредственными сельскими товаропроизводителями «не замечается» также, как и научные разработки, посвященные ее разрешению, не осознаются, не принимаются к применению, к внедрению. Инертное отношение участников аграрного производства всех уровней к использованию научного потенциала генерирует опасное социальное событие, а именно - бездействие в формах невмешательства, неведения, уклонения ${ }^{9}$, и формирует значительные имущественные потери. По данным РАСХН, «...потенциальные потери урожая в результате нашествий вредителей и возбудителей болезней растений превышают 100 млн. т в зерновых единицах. Риски опасных сорняков, конкурирующих с культурными растениями и выносящих из почвы более 5 млн. т питательных веществ, в 2 раза выше объемов вносимых минеральных удобрений. В экстремально-засушливых условиях на мелиорированных землях можно было бы гарантированно получить до 10 млн. т зерна. При увеличении ме-

${ }^{8}$ Алабушев В.А., Алабушев А.В. Указан. работа. С. 3; Васин В.Г., Васин А.В., Ельчанинова Н.Н. Растениеводство. - Самара.: РИЦ СГСХА, 2009. - 528 с. - С. 3; Ушачев И. Научное обеспечение стратегии социальноэкономического развития АПК России // АПК: экономика и управление. 2011. № 3. С. 11.

9 Ханнанов Р.А. Правовая природа бездействия и каузальность // Советское государство и право. 1978. № 4. C. 124-128. 


\section{Политика и общество 10 (106) • 2013}

лиорированных земель до 15 млн. га «подушка» зерновой безопасности составит 30 млн. т» ${ }^{10}$.

Равнодушная, бездеятельная позиция сельских товаропроизводителей по отношению к научным новациям преобразуется в форму отвержения научных разработок, в непринятие рекомендаций и, даже, неисполнение предписанных действий. В результате этого выгодные предложения научных учреждений остаются на бумаге в виде пожеланий, деклараций, легитимированных государством документах типа стратегий, программ, рекомендаций, технологических регламентов и др. В таком положении находятся и системы ведения сельского хозяйства (агропромышленного комплекса), составленные в регионах. Конкретные исполнители, как правило, не соблюдают их нормы-правила под разными предлогами, коих огромное множество, от объективного до субъективного характера. Для иллюстрации приведем лишь один пример, связанный с внедрением в производство адаптивно-контурных систем земледелия - главной материальной основы растениеводства. В ряде случаев контурная обработка земельных угодий, особенно вспашки, невозможна из-за объективной причины исполнения - географической непригодности конфигураций участков (узости, их продолговатости, высокой степени рассеченности и т.п.) и большой экономической расходности горюче-смазочных материалов, частых поломок технических средств обработки почв и машин и т.д. На ровных участках земли она вовсе не требуется из-за правильной геометрической расположенности.

Субъективные причины невнедрения этой системы преодолимы и не могут быть основанием для устранения от ее адаптации к конкретным условиям хозяйствования.

Современное растениеводство неполно ориентировано на реализацию таких естественно предопределенных возможностей обеспечения роста урожайности культур и сбора, как селекция, выведение новых разновидностей и сортов культурных растений. Практическая деятельность в этом направлении в отрасли почти не ведется. Разработанное И.В. Мичуриным положение о единстве организма и сферы жизнедеятельности и наследовании свойств, приобретаемых растениями в

${ }_{10}$ Ушачев И. Указ. Работа. С. 17-18. процессе их развития под влиянием изменившихся условий жизни, на деле отвергается. Это бескомпромиссно подтверждается, например, фактами игнорирования аутбридинга - разведения неродственных организмов разных видов и сортов, используемого для предотвращения вредных последствий близкородственного скрещивания. Посевы в хозяйствах осуществляются в устоявшемся, старом, не учитывающем природой обусловленные резервы производства, режиме. В севооборотах нет сочетаемости возделываемых культур с донороносителями, улучшателями биологических показателей увеличения отдачи урожаев. Вследствие этого посевы подвергаются влиянию инщухта - депрессивного, вредоносного явления, внешне выражающегося в виде короткостебельности, скороспелости и неполновесности плодов растений, особенно зерновых и корневых культур. Причины зарождения и развития инцухта малоизучены, сводятся они к теоретическим исследованиям разъяснительного характера, не дающим положительного эффекта - эффективности и устойчивости аграрного производства.

Выход из создавшегося положения видится в создании селексрассадников в структуpe селекционных центров, специализирующихся на изучении инцухт-линий, генерирующих гомозиготность (особенности наследственности растительного организма, возникающие как результат его происхождения от родителей, относительно сходных по своей наследственности), и разработке мер борьбы с инцухтом, а в надлежащих случаях - и по применению его природных ресурсных возможностей в сельскохозяйственном производстве во влагоизбыточных районах и регионах, испытывающих отрицательное воздействие ветровой эрозии почв, вызывающей полегание и гибель посевов.

Предложенные здесь рекомендации по борьбе с инцухтом, как нам кажется, смогли бы перенести центр тяжести по обеспечению продовольственной безопасности страны в какой-то мере и на плечи самих сельскохозяйственных товаропроизводителей.

Приведенные выше примеры свидетельствуют о серьезной деградации объективного фактора воспроизводства - ухудшении природной основы растениеводства, отрицательно влияющем 
на прогресс сельской отрасли и АПК, инициируя возвращение к экстенсивным формам и методам хозяйствования на селе (отсутствие селекции семян и культур на устойчивость производства и хранения, повышение уровня клейковины в зерне, сахаристости свеклы, игнорирование требований к размещению культур в севооборотах и др.). По данным МСХА им. К.А. Тимирязева, в полеводстве применяются лишь 10-15\% технологий интенсивного ресурсосберегающего типа ${ }^{11}$, размеры и объемы урожаев предопределяются, как правило, естественным плодородием ${ }^{12}$ и складывающимися погодными условиями. Не случайно РАСХН отметила значимость и своевременность создания концепции формирования государственно-рыночного механизма обеспечения технологического развития растениеводства, методических положений по оценке объективно складывающихся в аграрном секторе экономики кризисных (событийных) явлений, вызванных функционированием сельскохозяйственных товаропроизводителей в условиях рисков и разработки организационно-экономической модели зернопродуктового кластера региона ${ }^{13}$.

Такой подход к дальнейшему развитию растениеводства безусловно оправдан и должен быть признан научно обоснованным и обусловленным потребностями практики хозяйствования на селе $^{14}$, а также, если заглянуть глубже - в био-

${ }^{11}$ Голубев А.В. Блеск и нищета российского агрокомплекса // Экономика сельскохозяйственных и перерабатывающих предприятий. 2011. № 2. С. 8.

12 Алтухов A. Новые проблемы развития зерновой отрасли // АПК: экономика, управление. 2011. № 1. С. 10, 14-15.

13 Лубков А.Н. Приоритетные направления развития аграрно-экономических исследований на современном этапе // АПК: экономика, управление. 2013. № 2. С. 1-4.

14 Вагизова В.И. Экономические проблемы регионов и отраслевых комплексов // Проблемы современной экономики. 2009. № $3 / / \mathrm{http}: / / \mathrm{www} . \mathrm{m}$-economy.ru/art. php?nArtId=2795; Кормакова Е.С., Мокичев С.В. Агломерации - стратегическая составляющая устойчивости развития региональной экономической системы // Экономическме науки. 2011. № 8. С. 99-103; Батищева E.A., Bащенко A.A. Анализ факторов процессов в кластеризации в региональной экономике // Управление экономическими системами (электронный научный журнал). 2012. № 2; Черняев А., Сердобинцев Д. Организационно-экономический механизм формирования агропро- логию растений, и генетический сущностью последних ${ }^{15}$. Однако он не исчерпывает всей проблематики, связанной с научным обеспечением сельскохозяйственного производства, с учетом в нем природного фактора, адаптацией его к новым условиям существования ${ }^{16}$. Требуется особое внимание семеноводству, борьбе с засухой и внедрению «сухого земледелия», совершенствованию структуры посевных площадей, минимизации потерь от экстремальных явлений природы, привлечению биоресурсов, особенно органики (торфа, сапропеля, навоза и др.) на нужды растениеводства, расширению растениеводческого пространства Дальнего Востока и севера страны и т.д. Кластерная политика в России плохо осмыслена, не определена естественная сторона ее процесса формирования, что мешает активизации и концентрации производственных возможностей товаропроизводителей, повышению результатов их деятельности и в растениеводстве.

На эти и им подобные объективно предопределяемые обстоятельства, в частности, на нарастание негативных процессов, разрушающих земельный потенциал (водную и ветровую эрозии, опустынивание, обеднение почв и др.) в стране нет должной реакции со стороны органов государственной власти и хозяйственного управления, что вызвало обоснованную реакцию ученой общественности в виде открытого письма Президенту Российской Федерации, Правительству Российской Федерации и Государственной Думе и Совету Федерации «О необходимых мерах по созданию эффективной системы регулирования земельных отношений в Российской Федерации» ${ }^{17}$. Как показала практика нормативного регулирования аграрных

мышленных кластеров в Поволжье // АПК: экономика, управление. 2012. № 2. С. 3-8; Ханнанов Р.А., Ханнанова T.P. Кластеризация экономики и государственная кластерная политика: теоретические основы и социально-экономические предпосылки // Евразийский юридический журнал. 2012. № 12. С. 129-195.

${ }^{15}$ Сальникова Е. Факторы эффективности инновационного развития зернового производства // АПК: экономика, управление. 2013. № 7. С. 69.

16 Романенко $Г$. Деятельность российской академии сельскохозяйственных наук в 2012 году // АПК: экономика, управление. 2012. № 3. С. 3.

17 АПК: экономика, управление. 2013. № 5. С. 3-7. 


\section{Политика и общество 10 (106) 2013}

отношений, внешне переживающего бурное развитие в силу перехода от ведомственного регламентирования на федеральную законодательную основу, законодательные акты на деле оказались актами формального, декларативного порядка. Они «не работают», решения, принимаемые в соответствии с их нормами, в лучшем случае носят паллиативный характер, а предложения научных формирований не доходят до непосредственных исполнителей - хозяйств, в значительной части игнорируются ${ }^{18}$, а в ряде случаев вообще не реализуются из-за необоснованности, природной невосприимчивости, объективной неисполнимости. Примеры тому - предотвращение выноса питательных веществ из почвы; изменения климата и связанных с ним рисков; биологическая генуинность растений, обуславливающая повсеместную адаптивность их к сложившимся условиям произрастания; конкуренция сорняков с культурными растениями; реконструкция существующих и строительство новых мелиоративных систем, предусмотренных Концепцией по мелиорации; обеспечение чистоты и высокой продуктивности растений и другие природно предопределенные меры, тесно переплетенные с наукой и требующие долгих сроков их претворения в жизнь, в силу этого пребывающие до поры до времени на догматическом уровне и занимающие положение пожеланий и рекомендаций ко внедрению.

В факторальной системе развития растениеводства главное место должно быть предоставлено объективному, в первую очередь, самой природе человека - потенциального сельского товаропроизводителя, естественного обладателя приверженности сельскому образу жизни и труда, заинтересованного в результатах развития аграрного производства. Эта сторона вопроса постепенно уходит из поля зрения российского государства, да и сельского сообщества. По сведениям РАСХН, в настоящее время лишь

18 Ушачев И. Научное обеспечение Государственной программы развития сельского хозяйства и регулирования рынков сельскохозяйственной продукции, сырья и продовольствия на 2013-2020 гг. // АПК: экономика, управление. 2013. № 3. С. 13-26; его же. Научное обеспечение стратегии социально-экономического развития АПК России // Там же. С. 11-24.
45\% фермерских хозяйств реально ведут сельскохозяйственное производство ${ }^{19}$. Подобное состояние фермерства в стране формирует скрытый процесс реинтеграции в аграрной сфере экономики, в ее земледельческой подотрасли, которая может создать условия для дальнейшего развала сельского хозяйства всей федерации, тем самым детерминируя и нигилистическое отношение к возможностям природного потенциала агропрома и самой аграрной политике государства. Значительная часть производства сельскохозяйственной продукции ложится на плечи не полностью дееспособных, большей частью убыточных, находящихся на грани банкротства, сельскохозяйственных предприятий, а также личных хозяйств населения.

Преодоление тенденции процесса реинтеграции, как нам представляется, лежит на пути реанимации неиспользованных, естественно присущих человеку свойств и способностей ${ }^{20}$.

Таковы архиважные проблемы, связанные с объективной природной составляющей растениеводства, его органического компонента осуществления. Для понимания сущности природных процессов, происходящих в недрах растениеводческой деятельности и учета ее особенностей в организации и ведении аграрного производства, в особенности в деле адаптации к зональным, в пределах зон - к конкретным условиям ведения производства, оно рассматривается с дизъюнктивных позиций. И только. Разделение здесь не означает противопоставление содержания и формы, объективного и субъективного (осознанного, признанного и познанного) и предполагает целью обеспечения в ходе субъективного достижения общепо-

\footnotetext{
19 Лубков А.Н. Приоритетные направления развития аграрно-экономических исследований на современном этапе // АПК: экономика, управление. 2013. № 2. С. 4.

${ }^{20}$ Ханнанова T.P. Аграрная политика государства: критика догмы // Теория и практика общественного развития. 2013. С. 187-190: ее же. Объективные основы формирования и реализации государственной аграрной политики // Исторические, философские, политические и юридические науки и искусствоведение. Вопросы теории и практики. 2013. № 6. С. 184-190; ее же. Реализация аграрной политики государства: принципиальные основы // Политика и общество. 2013. № 5. C. 630-639.
} 
лезного экономического результата - рост эффективности и устойчивости растениеводства. Достичь этот результат возможно только на основе симбиоза объективного и субъективного, так как именно закономерное сочетание объективного и субъективного предопределяет успешность хозяйствования, становится правилом экономического поведения сельских товаропроизводителей, а также предтечей обновления, разработки и принятия аграрной политики российского государства ${ }^{21}$.

На основании проведенного исследования можно сделать следующие выводы:

1. объективная природа растениеводства (одной из основных подотраслей сельского хозяйства) является важнейшим и неустранимым фактором формирования и реализации аграрной политики государства;

2. игнорирование политическими акторами объективной природы растениеводства ведет в конечном счете к неэффективности аграрной политики и формированию у населения и хозяйствующих субъектов недоверия к ней, к нигилистическому отношению к принимаемым политически значимым решениям государства в сфере аграрных отношений;

3. современное отсталое бытие растениеводства в России во многом предопределяется неэффективностью проводимой аграрной политики, которая, в свою очередь, системно не учитывает природную обусловленность этой сферы человеческой жизнедеятельности;

4. аграрная политика государства обладает свойством природной предопределенности. Это свойство неустранимо, непреодолимо, вечно и всеобъемлюще как сама природа. Исходя из этого, все элементы аграрной политики (приоритеты, цели, задачи, ресурсы, решения, действия, конечные результаты, контроль исполнения, оценка эффективности) должны формироваться и реализовываться в рамках признания и осознания политическими акторами объективной природой предопределенности этих элементов и аграрной политики в целом.

${ }^{21}$ Об этом подробно см. Ханнанова Т.Р. Государственная аграрная политика: проблемы объективации // Право и политика. 2013. № 4. С. 489-498.

\section{Библиография:}

1. Р.А. Ханнанов, Т.Р. Ханнанова. События в системе правового обеспечения модернизации социально-экономического развития России: теория и практика [Текст] - Уфа: Башкирский ГАУ, АН РБ, 2012. - 162 с. С. 16-26, 36-44.

2. Краснов В.М. К понятию общества как социальной системы [Текст] // Философские науки. 1977. № 2. С. 28.

3. Ханнанов Р.А., Ханнанова Т.Р. События в системе правового обеспечения модернизации социально-экономического развития России: теория и практика [Текст] - Уфа: Башкирский ГАУ, АН РБ, 2012. - 162 с. С. 65-114; их же. Модернизация государственной аграрной политики государства [Текст] - Уфа, Академия наук РБ, ФГБОУ ВПО «Башкирский государственный аграрный университет», 2013. 484 с. - С. 4-237.

4. Алабушев В.А., Алабушев А.В. Растениеводство / Под ред. Алабушева В.А. [Текст] - Ростов н/Д, Издательский центр «Март», 2001. 384 c. - C. 3.

5. Коренев Г.В., Федотов В.А., Попов А.Ф. и др. Растениеводство [Текст] - М.: Колос, 1999. - 368 с. - С. 3.

6. Ханнанова Т.Р. Государственная аграрная политика: проблемы объективации [Текст] // Право и политика. 2013. 3 4. С. 498.

7. Система ведения агропромышленного производства в Республике Башкортостан [Текст] - Уфа.: АН РБ, Гилем, 2012. - 528 с.

8. Васин В.Г., Васин А.В., Ельчанинова Н.Н. Растениеводство [Текст]-Самара.: РИЦ СГСХА, 2009. - 528 с. - С. 3; Ушачев И. Научное обеспечение стратегии социально-экономического развития АПК России [Текст] // АПК: экономика и управление. 2011. № 3. С. 11.

9. Ханнанов Р.А. Правовая природа бездействия и каузальность [Текст] // Советское государство и право. 1978. № 4. С. 124-128.

10. Ушачев И. Научное обеспечение стратегии социально-экономического развития АПК России [Текст] // АПК: экономика и управление. 2011. № 3. С. 17-18.

11. Голубев А.В. Блеск и нищета российского агрокомплекса [Текст] // Экономика сельско- 


\section{Политика и общество 10 (106) • 2013}

хозяйственных и перерабатывающих предприятий. 2011. № 2. С. 8.

12. Алтухов А. Новые проблемы развития зерновой отрасли [Текст] // АПК: экономика, управление. 2011. № 1. С. 10, 14-15.

13. Лубков А.Н. Приоритетные направления развития аграрно-экономических исследований на современном этапе [Текст] // АПК: экономика, управление. 2013. № 2. С. 1-4.

14. Вагизова В.И. Экономические проблемы регионов и отраслевых комплексов [Электронный ресурс] // Проблемы современной экономики. 2009. № 3 // http://www.m-economy. ru/art.php?nArtId=2795; Кормакова Е.С., Мокичев С.В. Агломерации - стратегическая составляющая устойчивости развития региональной экономической системы [Текст] // Экономическме науки. 2011. № 8. С. 99103; Батищева Е.А., Ващенко А.А. Анализ факторов процессов в кластеризации в региональной экономике [Текст] // Управление экономическими системами (электронный научный журнал). 2012. № 2; Черняев А., Сердобинцев Д. Организационно-экономический механизм формирования агропромышленных кластеров в Поволжье [Текст] // АПК: экономика, управление. 2012. № 2. C. 3-8; Ханнанов Р.А., Ханнанова Т.Р. Кластеризация экономики и государственная кластерная политика: теоретические основы и социально-экономические предпосылки [Текст] // Евразийский юридический журнал. 2012. № 12. С. 129-195.

15. Сальникова Е. Факторы эффективности инновационного развития зернового производства [Текст] // АПК: экономика, управление. 2013. № 7. С. 69.

16. Романенко Г. Деятельность российской академии сельскохозяйственных наук в 2012 году [Текст] // АПК: экономика, управление. 2012. № 3. С. 3.

17. АПК: экономика, управление [Текст]-2013. № 5. С. 3-7.

18. Ушачев И. Научное обеспечение Государственной программы развития сельского хозяйства и регулирования рынков сельскохозяйственной продукции, сырья и продовольствия на 2013-2020 гг. [Текст] // АПК: экономика, управление. 2013. № 3. С.
13-26; его же. Научное обеспечение стратегии социально-экономического развития АПК России [Текст] // АПК: экономика, управление. 2013. № 3. С. 11-24.

19. Лубков А.Н. Приоритетные направления развития аграрно-экономических исследований на современном этапе [Текст] // АПК: экономика, управление. 2013. № 2. С. 4.

20. Ханнанова Т.Р. Аграрная политика государства: критика догмы [Текст] // Теория и практика общественного развития. 2013. С. $187-$ 190: ее же. Объективные основы формирования и реализации государственной аграрной политики [Текст] // Исторические, философские, политические и юридические науки и искусствоведение. Вопросы теории и практики. 2013. № 6. С. 184-190; ее же. Реализация аграрной политики государства: принципиальные основы [Текст] // Политика и общество. 2013. № 5. С. 630-639.

21. Ханнанова Т.Р. Государственная аграрная политика: проблемы объективации [Текст] // Право и политика. 2013. № 4. С. 489-498

\section{References (transliteration):}

1. R.A. Khannanov, T.R. Khannanova. Sobytiya v sisteme pravovogo obespecheniya modernizatsii sotsial'no-ekonomicheskogo razvitiya Rossii: teoriya i praktika [Tekst] - Ufa: Bashkirskii GAU, AN RB, 2012. - 162 s. S. 16-26, 36-44.

2. Krasnov V.M. K ponyatiyu obshchestva kak sotsial'noi sistemy [Tekst] // Filosofskie nauki. 1977. № 2. S. 28.

3. Khannanov R.A., Khannanova T.R. Sobytiya v sisteme pravovogo obespecheniya modernizatsii sotsial'no-ekonomicheskogo razvitiya Rossii: teoriya i praktika [Tekst] - Ufa: Bashkirskii GAU, AN RB, 2012.-162 s. S. 65-114; ikh zhe. Modernizatsiya gosudarstvennoi agrarnoi politiki gosudarstva [Tekst] - Ufa, Akademiya nauk RB, FGBOU VPO «Bashkirskii gosudarstvennyi agrarnyi universitet», 2013. 484 s. S. 4-237.

4. Alabushev V.A., Alabushev A.V. Rastenievodstvo / Pod red. Alabusheva V.A. [Tekst] - Rostov n/D, Izdatel'skii tsentr «Mart», 2001. 384 s. S. 3 . 
5. Korenev G.V., Fedotov V.A., Popov A.F. i dr. Rastenievodstvo [Tekst] - M.: Kolos, 1999. 368 s. - S. 3.

6. Khannanova T.R. Gosudarstvennaya agrarnaya politika: problemy ob' 'ektivatsii [Tekst] // Pravo i politika. 2013. 3 4. S. 498.

7. Vasin V.G., Vasin A.V., El'chaninova N.N. Rastenievodstvo [Tekst]-Samara.: RITs SGSKhA, 2009. - 528 s. - S. 3; Ushachev I. Nauchnoe obespechenie strategii sotsial'no-ekonomicheskogo razvitiya APK Rossii [Tekst] // APK: ekonomika i upravlenie. 2011. № 3. S. 11.

8. Khannanov R.A. Pravovaya priroda bezdeistviya i kauzal'nost' [Tekst] // Sovetskoe gosudarstvo i pravo. 1978. № 4. S. 124-128.

9. Ushachev I. Nauchnoe obespechenie strategii sotsial'no-ekonomicheskogo razvitiya APK Rossii [Tekst] // APK: ekonomika i upravlenie. 2011. № 3. S. 17-18.

10. Golubev A.V. Blesk i nishcheta rossiiskogo agrokompleksa [Tekst] // Ekonomika sel'skokhozyaistvennykh i pererabatyvayushchikh predpriyatii. 2011. № 2. S. 8.

11. Altukhov A. Novye problemy razvitiya zernovoi otrasli [Tekst] // APK: ekonomika, upravlenie. 2011. № 1. S. 10, 14-15.

12. Lubkov A.N. Prioritetnye napravleniya razvitiya agrarno-ekonomicheskikh issledovanii na sovremennom etape [Tekst] // APK: ekonomika, upravlenie. 2013. № 2. S. 1-4.

13. Vagizova V.I. Ekonomicheskie problemy regionov i otraslevykh kompleksov [Elektronnyi resurs] // Problemy sovremennoi ekonomiki. 2009. № 3 // http://www.m-economy.ru/art. php?nArtId=2795; Kormakova E.S., Mokichev S.V. Aglomeratsii - strategicheskaya sostavlyayushchaya ustoichivosti razvitiya regional'noi ekonomicheskoi sistemy [Tekst] // Ekonomicheskme nauki. 2011. № 8. S. 99-103; Batishcheva E.A., Vashchenko A.A. Analiz faktorov protsessov v klasterizatsii $\mathrm{v}$ regional'noi ekonomike [Tekst] // Upravlenie ekonomicheskimi sistemami (elektronnyi nauchnyi zhurnal). 2012. № 2; Chernyaev A., Serdobintsev D.
Organizatsionno-ekonomicheskii mekhanizm formirovaniya agropromyshlennykh klasterov v Povolzh'e [Tekst] // APK: ekonomika, upravlenie. 2012. № 2. S. 3-8; Khannanov R.A., Khannanova T.R. Klasterizatsiya ekonomiki i gosudarstvennaya klasternaya politika: teoreticheskie osnovy i sotsial'no-ekonomicheskie predposylki [Tekst] // Evraziiskii yuridicheskii zhurnal. 2012. № 12. S. 129-195.

14. Sal'nikova E. Faktory effektivnosti innovatsionnogo razvitiya zernovogo proizvodstva [Tekst] // APK: ekonomika, upravlenie. 2013. № 7. S. 69.

15. Romanenko G. Deyatel'nost' rossiiskoi akademii sel'skokhozyaistvennykh nauk v 2012 godu [Tekst] // APK: ekonomika, upravlenie. 2012. № 3. S. 3 .

16. Ushachev I. Nauchnoe obespechenie Gosudarstvennoi programmy razvitiya sel'skogo khozyaistva i regulirovaniya rynkov sel'skokhozyaistvennoi produktsii, syr'ya i prodovol'stviya na 2013-2020 gg. [Tekst] // APK: ekonomika, upravlenie. 2013. № 3. S. 13-26; ego zhe. Nauchnoe obespechenie strategii sotsial'no-ekonomicheskogo razvitiya APK Rossii [Tekst] // APK: ekonomika, upravlenie. 2013. № 3. S. 11-24.

17. Lubkov A.N. Prioritetnye napravleniya razvitiya agrarno-ekonomicheskikh issledovanii na sovremennom etape [Tekst] // APK: ekonomika, upravlenie. 2013. № 2. S. 4.

18. Khannanova T.R. Agrarnaya politika gosudarstva: kritika dogmy [Tekst] // Teoriya i praktika obshchestvennogo razvitiya. 2013. S. 187-190: ee zhe. Ob"'ektivnye osnovy formirovaniya i realizatsii gosudarstvennoi agrarnoi politiki [Tekst]//Istoricheskie, filosofskie, politicheskie $\mathrm{i}$ yuridicheskie nauki i iskusstvovedenie. Voprosy teorii i praktiki. 2013. № 6. S. 184190; ee zhe. Realizatsiya agrarnoi politiki gosudarstva: printsipial'nye osnovy [Tekst] // Politika i obshchestvo. 2013. № 5. S. 630-639.

19. Khannanova T.R. Gosudarstvennaya agrarnaya politika: problemy ob' ektivatsii [Tekst] // Pravo i politika. 2013. № 4. S. 489-498 